\title{
Evaluation of Haematological Parameters among Cigarette Smokers who Drink local Gin in Ogba/ Egbema/ Ndoni Local Government area of Rivers State
}

\author{
Ilueme C. Precious ${ }^{1}$, Tombotamunoa W. J. Lawson ${ }^{2}$ and N. C. Ibeh ${ }^{3}$ \\ ${ }^{1}$ Rivers State Ministry of Health, Port Harcourt, Nigeria. \\ ${ }^{2}$ Department of Mathematics/Statistics, Ignatius Ajuru University of Education, PMB 5047, Port Harcourt, Nigeria. \\ ${ }^{3}$ Department of Medical Laboratory Sciences, Nnamdi Azikiwe University, Awka, Nigeria.
}

\begin{abstract}
Cigarette and cannabis smoking and drinking local gin are closely associated with people of different age groups. This study focused on the haematological evaluation of the effect of local gin consumption alongside cigarette and cannabis smoking on haematological parameters in residents of Ogba/Egbema/Ndoni Local Government of Rivers State. One hundred and eighty subjects were recruited for this study and the age bracket was between 22 - 65 years. Thirty of the subjects served as the control, thirty other subjects were drinkers of local gin alone, thirty other subjects were smokers of the mainly donchester brand of cigarette and cannabis popularly called "igboo" and the remaining ninety subjects were drinkers of local gin who also smokes cigarette and cannabis. The subjects $4 \mathrm{ml}$ of blood was withdrawn into EDTA specimen container for full blood count assay after obtaining consent from the subjects. BC-2800 Auto Haematology Analyzer was used for the assay for FBC while Westergren method was used for erythrocyte Sedimentation Rate (ESR). Statistical package for the Social Sciences (SPSS) Version 21 was used for analysis for mean, standard deviation, ANOVA and correlation. The results showed that mean cell volume (MCV), Packed cell volume $(P C V)$, White blood cell (WBC), Red blood cell (RBC), and neutrophil were significantly higher in local gin drinkers who also smoke cigarette $P<0.05$ compared with control. Conversely, the erythrocyte sedimentation rate, platelet, heaemoglobin, mean cell haemoglobin, mean cell haemoglobin concentration, monocytes, lymphocytes were not significant when compared with the control. The results showed that neutrophil increased significantly with $P$-value of 0.16 and $F=1.89$, Mean cell volume increased
\end{abstract}

significantly with P-value 0.23, Red blood cell increased significantly with $P$-value 0.34 , White blood cell increased significantly with P-value 0.20 and PCV increased significantly with a P-value of 0.55 . The correlation of the parameters that showed increased significance among the subjects showed MCV $=0.54$ among local gin drinkers who smoke and local gin drinkers alone, but the $R B C=-0.67$ among cigarette smokers who drink local gin and only smokers alone, correlation among local gin consumers only and cigarette smokers alone showed $M C V=0.131, W B C=$ 1.45 and $P C V=0.45$. Therefore, this study suggests that a significant increase in neutrophil, RBC, MCV, WBC and $P C V$ may be due to frequent consumption of local gin and frequent smoking of cannabis and cigarette. Drinkers of local gin and smokers of cigarette and cannabis in Ogba/Egbema/Ndoni Local Government Area should be informed of the implications of this social habit in their haematological parameters.

Keywords- Haematological, Local gin, Cigarette, Smokers and drinkers.

\section{INTRODUCTION}

Local gin and cigarette smoking are seen as a social habit of so many alcoholics that we see in water side environments and environments that some form of street hideouts are known for especially in environment or areas that are prone to crisis and cult activities. Local gin is called different names for different people and in a different area, such names are ogogoro, kai-kai, root and hard man. Cigarette smokers of different brands are often times associated with alcohol consumption. In the local areas where this research was conducted are mainly smokers who are local gin 
drinkers especially in small corners of the street called "joint." They can always be seen early hours of the morning in those areas and most of them are low-income earners to middle-income earners.

Haematological parameters are of immense importance as they provide diverse and vital information about a population under investigation (Ernst et.al; 1990). Several factors determine the value of any particular haematological parameters under assessment (Ernst et.al; 1990); the importance of various population and gender-specific reference values cannot therefore be over emphasized (Dirren et.al; 1991).

Most of the studies done in the area of cigarette smoking and alcohol consumption has always seemed to be subjective because there are different brands of cigarette as well as different brands of alcoholic beverages with different concentration of alcohol and by so all are generalized as smoking cigarette and drinking alcohol.

Smoking and drinking has shown to raise mean cell volume but does not affect haemoglobin, Red blood cell count and leucocytes counts (Carole, 2010). Heavy smoking and heavy drinking have also increased haemoglobin concentration of the blood. Alcohol consumption decreases white blood cell count but cigarette smoking increases the total peripheral blood leucocyte.

\section{OBJECTIVES OF THE STUDY}

1. To determine the haematological parameters among local gin drinkers.

2. To determine haematological parameters among cigarette smokers.

3. To evaluate the relationship between local gin consumption and smoking on haematological parameters

Cigarette smoking and alcohol consumption have been found to be a major depressive disorder in leucocyte count for men (Surtees, 2003).

The most common brand of cigarette younger generations smoke is Donchester and cannabis but the older generations smoke mainly Benson and Hedges. Rivers State Government banned the sale and consumption of Local gin in the State due to the death of about 66 persons in Woji town and Trans-Amadi (DailyPost, 2015). Cigarette packs are clearly written with an inscription that the federal Ministry of health warns that smokers are liable to die young and cannabis smokers see cannabis in a different light from other brands of cigarettes. That informs the reason for this research work.

According to 2006 census, Ogba/Egbema/Ndoni Local Government Area of Rivers State is said to have a population of about 218,350 persons. Ogba/Egbema/Ndoni Local Government Area is located within the Orashi region of Rivers State where oil is the most abundant mineral resources. It is a local Government that has people of four different languages such as Egbema speaking, Egi speaking, Omoku speaking, and Ndoni spoken languages. The area is known for its oil and gas-rich environment but a lot of the youths and elderly are of low-income earners and middleincome earners despite the fact that it is acclaimed that three major oil multinational companies residing in the area will make the people of the area rich.

\subsection{Study sites}

This study was carried out in Ogba/Egbema/Ndoni Local Government Area of Rivers State, Nigeria with the approval of Ogba/Egbema/Ndoni Community Healthcare Ethics Committee.

\subsection{Sample Size.}

For calculating sample size, the formula proposed by Cochran, (1977) was adopted and a total of 180 adult volunteers between the ages of 22-65 years were recruited.

\subsection{Sample Collection}

Four milliliters of the venous blood sample was collected from the median antecubital vein of the subjects left upper limb in the morning hours between 7 a.m to 8 a.m and it was in the fasting state for all the subjects. The $4 \mathrm{ml}$ of blood was taken with the aid of syringe and put in Ethylenediaminetetraacetic acid (EDTA) bottle. The time between collection and assay was between 1-2hours. Auto Haematology Analyzer BC-2800 was used to determine the complete blood count, and Erythrocyte Sedimentation Rate (ESR) was performed using the Westergren Method.

\subsection{Statistical Method}

Statistical analysis was done using software; Statistics Package for Social Sciences (SPSS) version 20. Analysis of variance (ANOVA) was used to compare parameters among groups, descriptive statistics were also used (Mean and Standard deviation) to compare between groups. An alpha value of $<0.05$ denoted a statistically significant difference. 


\section{RESULTS}

Table.4.1: Haematological parameters of smokers and control.

\begin{tabular}{|c|c|c|c|c|}
\hline \multirow[t]{2}{*}{ Parameters } & Control & Smokers & F Value & P-value \\
\hline & $\mathrm{N}=30$ & $\mathrm{~N}=30$ & & \\
\hline Neutrophils (\%) & $31.9 \pm 15.2$ & $34.3 \pm 8.2$ & 1.89 & 0.16 \\
\hline Haemoglobin $(\mathrm{g} / \mathrm{dl})$ & $149 \pm 2.5$ & $16.1 \pm 2.45$ & 4.9 & 0.01 \\
\hline PCV (\%) & $53.8 \pm 9.0$ & $60.5 \pm 15.4$ & 0.604 & 0.55 \\
\hline $\operatorname{RBC}\left(10^{28} / \mathrm{L}\right)$ & $6.08 \pm 1.4$ & $5.4 \pm 2.45$ & 1.094 & 0.34 \\
\hline WBC $\left(10^{9} / \mathrm{L}\right)$ & $4.3 \pm 1.6$ & $7.2 \pm 2.5$ & 1.65 & 0.20 \\
\hline ESR $(\mathrm{mm} / \mathrm{hr})$ & $21.1 \pm 9.7$ & $35.3 \pm 27.3$ & 4.75 & 0.01 \\
\hline MCV (fl) & $85.0 \pm 7.9$ & $87.9 \pm 6.9$ & 1.52 & 0.23 \\
\hline $\mathrm{MCH}(\mathrm{pg})$ & $23.4 \pm 2.34$ & $26.0 \pm 2.97$ & 4.85 & 0.01 \\
\hline Platelet count & $231.7 \pm 92.8$ & $135 \pm 92.8$ & 6.25 & 0.004 \\
\hline$\left(10^{9} / \mathrm{L}\right)$ & $13.9 \pm 8.7$ & $15.3 \pm 3.8$ & 3.1 & 0.05 \\
\hline Monocytes (\%) & $56.2 \pm 13.4$ & $50.3 \pm 6.9$ & 2.4 & 0.10 \\
\hline Lymphocytes (\%) & $23.4 \pm 2.3$ & $34.3 \pm 2.1$ & 4.8 & 0.00 \\
\hline \multicolumn{5}{|l|}{ MCHC $(\mathrm{g} / \mathrm{L})$} \\
\hline \multicolumn{5}{|c|}{$\begin{array}{c}\text { are mean } \pm \text { SD. Key words: Packed cell volume (PCV), Mean cell volume (MCV), } \\
\text { Mean cell Haemoglobin }(\mathrm{MCH}) \text {, Mean cell haemoglobin concentration (MCHC), Red blo } \\
\text { Table.4.2: Haematological parameters of drinkers and control }\end{array}$} \\
\hline neters & Control & Drinkers & $\mathrm{F}(\mathrm{P})$ Value & P-value \\
\hline rophils (\%) & $31.9 \pm 15.2$ & $32.2 \pm 8.7$ & 1.89 & 0.16 \\
\hline noglobin (g/dl) & $149 \pm 2.5$ & $16.5 \pm 2.5$ & 4.9 & 0.01 \\
\hline$(\%)$ & $53.8 \pm 9.0$ & $55.6 \pm 4.12$ & 0.604 & 0.55 \\
\hline$\left(10^{28} / \mathrm{L}\right)$ & $6.08 \pm 1.4$ & $6.57 \pm 1.3$ & 1.094 & 0.34 \\
\hline$\left(10^{9} / \mathrm{L}\right)$ & $4.3 \pm 1.6$ & $7.23 \pm 2.5$ & 1.65 & 0.20 \\
\hline$(\mathrm{mm} / \mathrm{hr})$ & $21.1 \pm 9.7$ & $15.6 \pm 8.8$ & 4.75 & 0.01 \\
\hline (fl) & $85.0 \pm 7.9$ & $87.7 \pm 4.68$ & 1.52 & 0.23 \\
\hline I (pg) & $23.4 \pm 2.34$ & $25.5 \pm 1.6$ & 4.85 & 0.01 \\
\hline let count $\left(10^{9} / \mathrm{L}\right)$ & $231.7 \pm 92.8$ & $199 \pm 60.2$ & 6.25 & 0.004 \\
\hline ocytes $(\%)$ & $13.9 \pm 8.7$ & $17.6 \pm 5.3$ & 3.1 & 0.05 \\
\hline phocytes (\%) & $56.2 \pm 13.4$ & $48.2 \pm 8.5$ & 2.4 & 0.10 \\
\hline $\mathrm{IC}(\mathrm{g} / \mathrm{L})$ & $23.4 \pm 2.3$ & $30.1 \pm 1.98$ & 4.8 & 0.00 \\
\hline
\end{tabular}

Results are mean \pm SD. Key words: Packed cell volume (PCV), Mean cell volume (MCV), Erythrocyte sedimentation rate (ESR), Mean cell Haemoglobin (MCH), Mean cell haemoglobin concentration (MCHC), Red blood cell (RBC), White blood cell (WBC). 
Table.4.3: Haematological parameters of ogogoro drinkers who smoke cigarettes and control.

\begin{tabular}{|c|c|c|c|c|}
\hline Parameters & $\begin{array}{l}\text { Control } \\
\mathrm{N}=30\end{array}$ & $\begin{array}{l}\text { Drinkers \& Smokers } \\
\mathrm{N}=90\end{array}$ & F (P) Value & P-value \\
\hline Neutrophils (\%) & $31.9 \pm 15.2$ & $36.6 \pm 6.98$ & 1.89 & 0.16 \\
\hline Haemoglobin (g/dl) & $149 \pm 2.5$ & $13.4 \pm 3.69$ & 4.9 & 0.01 \\
\hline $\operatorname{PCV}(\%)$ & $53.8 \pm 9.0$ & $51.1 \pm 14.9$ & 0.604 & 0.55 \\
\hline $\mathrm{RBC}\left(10^{28} / \mathrm{L}\right)$ & $6.08 \pm 1.4$ & $5.86 \pm 1.71$ & 1.094 & 0.34 \\
\hline WBC $\left(10^{9} / \mathrm{L}\right)$ & $4.3 \pm 1.6$ & $5.17 \pm 2.01$ & 1.65 & 0.20 \\
\hline ESR (mm/hr) & $21.1 \pm 9.7$ & $33.3 \pm 25.6$ & 4.75 & 0.01 \\
\hline $\operatorname{MCV}(\mathrm{fl})$ & $85.0 \pm 7.9$ & $89.4 \pm 7.86$ & 1.52 & 0.23 \\
\hline $\mathrm{MCH}(\mathrm{pg})$ & $23.4 \pm 2.34$ & $25.8 \pm 2.33$ & 4.85 & 0.01 \\
\hline Platelet count $\left(10^{9} / \mathrm{L}\right)$ & $231.7 \pm 92.8$ & $141 \pm 94.9$ & 6.25 & 0.004 \\
\hline Monocytes (\%) & $13.9 \pm 8.7$ & $12.7 \pm 4.58$ & 3.1 & 0.05 \\
\hline Lymphocytes (\%) & $56.2 \pm 13.4$ & $51.4 \pm 7.89$ & 2.4 & 0.10 \\
\hline $\mathrm{MCHC}(\mathrm{g} / \mathrm{L})$ & $23.4 \pm 2.3$ & $29.1 \pm 1.52$ & 4.8 & 0.00 \\
\hline
\end{tabular}

Results are mean \pm SD. Key words: Packed cell volume (PCV), Mean cell volume (MCV), Erythrocyte sedimentation rate (ESR), Mean cell Haemoglobin (MCH), Mean cell haemoglobin concentration (MCHC), Red blood cell (RBC), White blood cell (WBC).

Table.4.4: Correlation of Neutrophil, Packed cell volume, Red blood cell, White blood cell, and Mean cell volume.

\begin{tabular}{llllll}
\hline Parameters & Neutrophil & PCV & RBC & WBC & MCV \\
$\mathrm{r}$ & -2.6 & -0.49 & -1.68 & -0.543 & 0.54 \\
Significance & 0.16 & 0.55 & 0.342 & 0.202 & 0.229 \\
\hline
\end{tabular}

Table.4.5: Correlation of Neutrophil, packed cell volume, red blood cell, white blood cell, and mean cell volume among cigarette smokers who drink ogogoro and only cigarette smokers alone.

\begin{tabular}{|c|c|c|c|c|c|}
\hline Parameters & Neutrophil & $\mathrm{MCV}$ & $\mathrm{RBC}$ & $\mathrm{PCV}$ & $\mathrm{WBC}$ \\
\hline $\mathrm{r}$ & 0.6 & 1.53 & -0.67 & 21.86 & 4.43 \\
\hline significance & 0.16 & 0.55 & 0.342 & 0.202 & 0.229 \\
\hline
\end{tabular}

Table.4.6: Correlation of Neutrophil, packed cell volume, red blood cell, white blood cell, and mean cell volume.

\begin{tabular}{llllll}
\hline Parameters & Neutrophil & MCV & RBC & WBC & PCV \\
$\mathrm{r}$ & -4.67 & 0.131 & -1.031 & 1.45 & 0.43 \\
Significance & 0.16 & 0.55 & 0.342 & 0.229 & 0.202 \\
\hline
\end{tabular}

\section{DISCUSSION}

Several studies have shown that alcohol consumption and cigarette smoking has an impact on the blood cells (Jaana et.al., 2004 ; Paolo et.al., 1996) and also has effect also haematological parameters (Erhabor et.al., 2013). Cancer, cirrhosis of the liver, visual problems and many form of mental health is not just enough to show that alcohol and cigarette have effect on brain, liver, eye, heart, and blood vessels (Ross et.al., 2016). Therefore, in this study we decided to show the effect local gin that is locally brewed in Ogba/Egbema/Ndoni Local Government Area and other parts of West Africa especially Rivers State generally and cannabis smoking that you see young people wrap. To some extent, the results obtained from this research is not subjective like other research conducted on alcohol consumption by undermining brands and alcohol concentration of the different brands that are not brewed even in West Africa.

Chronic alcohol consumption has been suggested as one of the factors that may lead to hypocellularity (decreased production of the erythrocytes, leucocytes and thrombocytes). These lead to anaemia, leucopenia, thrombocytopenia and their relative sequelae (Latvala et.al., 2014 and Vatn et.al., 2001). 
In this study, among the three main red blood cell indices that help in measuring the average size and haemogobin composition of the red blood cells (MCV, MCH \& MCHC); the study established significantly larger values of mean cell volume among drinkers of local gin, smokers of cannabis and cigarette smoking and drinkers of local gin alongside cigarette and cannabis smoking, confirming a research by Asif et al., while MCHC showed no level of significance in the study among smokers, drinkers and smokers and drinkers $(\mathrm{P}=0)$ but the level of $\mathrm{MCH}$ among smokers, drinkers and smokers and drinkers were lowered. Although Asif et al., 2010 found an increase in MCV and decrease in $\mathrm{MCH}$ and MCHC levels of smokers. The finding of this research agrees with the finding made by (Salamzadeh, 2012) to some extent that the amounts of $\mathrm{MCH}$ and $\mathrm{MCHC}$ in smoker group were significantly lower $(\mathrm{P}<0.05)$ compared to non-smoker group.

The red blood cell level of smokers, drinkers and smokers who drink local gin increased as compared to the control subjects. This could be due to the level of smoking and consumption of local gin as well. This further confirms studies by (Maja et.al., 2017).

In this study, there was an increase in packed cell volume but a decrease in haemoglobin level among the smokers of cannabis, drinkers of local gin and smokers of cannabis who drink local gin. This supports a study by Lakshmi et.al 2012 that showed a significant increase in smokers haematocrit but this study contradicts his study that smoking also increases haemoglobin level. In this same study Lakshmi et.al 2012 also agreed that there was significant high red blood cell count in smokers and drinkers as the intensity of smoking and drinking increases. Increased number of red blood cell but decrease level of haemoglobin cannot be explained by the fact that tissue hypoxia caused by carbon monoxide leads to increased secretion of erythropoietin, thus causing erythropoiesis.

This study went further to show that erythrocyte sedimentation rate was significantly not elevated among smokers of cannabis and cigarette, drinkers of local gin and smokers of cannabis who drink local gin as compared to study that show showed a high level of erythrocyte sedimentation rate in chronic alcoholics compared to nonalcoholics (Erhabor, 2011; Wood 1987).

The platelet count showed that cannabis and cigarette smoking, local gin consumption and smoking and consuming local gin has a significant effect as compared to those who don't smoke, drink and smoke and drink alongside. Although similar studies showed that there is a significant difference between the platelet counts of chronic alcoholics and non-alcoholics, that thrombocytopenia was greatly significant among alcoholics compared to non alcoholics (Teddy et.al., 2013).

This study established a significantly larger number of white blood cells among smokers of cannabis and cigarette, drinkers of local gin and those who smoke cannabis and drink local gin alongside in comparison to the control group. The increased white blood cell count observed is similar to earlier studies (Maja, 2017; Inal, 2014; Higuchi, 2016). Although the exact mechanism of how smoking of cannabis and drinking of local gin increases the number and level of white blood cell is not well known

Some authors claim that an increase in the level of white blood cells can be the damage done by nicotine-induced release of catecholamines and steroid hormones from the core of the adrenal gland. It is not known that increase in the level of certain endogenic hormones, such as epinephrine and cortisol, results in an increase in the number of white blood cell (Kapoor, 2015; Deutsch, 2012).

The white blood cell differential that showed a significant increase is the neutrophil. A study also confirms that smoking and drinking increases the level of neutrophil (Oduola et.al., 2015). The neutrophil levels of smokers of cannabis, drinkers of local gin and smokers of cannabis who drink local gin respectively increased. But the lymphocyte count and monocyte count showed that local gin consumption, cannabis smoking and drinking local gin and smoking alongside did not have a significant effect as compared to the control subjects.

\section{CONCLUSION}

From the present study, we can conclude that cannabis and cigarette smoking increases red blood cells, white blood cells, mean cell volume, neutrophil count and packed cell volume, we also conclude that local gin consumption increases red blood cells, white blood cells, mean cell volume, neutrophil count and packed cell volume and lastly conclude that smokers of cannabis and cigarette who drink local gin has a significant increase in red blood cells, white blood cells, neutrophil count, packed cell volume and mean cell volume. The change in these haematological parameters might be associated with a greater risk for developing cardiac diseases such as atherosclerosis, polycythemia vera, and possible leucocytosis. 


\section{REFERENCES}

[1] Carole, L; George, D; Laurence, G and Graham, C (2010). The Combined effect of smoking tobacco and drinking alcohol on cause-specific mortality: a 30-year cohort study. BMC Public Health 10; pp789.

[2] Deutsch, V; Lerner-Geva, L; Reches, A; Boyko, V; Limor, R and Grisaru. D (2007). Sustained leukocyte count during rising cortisol level. Haematologica 118(2); pp 73-76.

[3] Erhabor, O 2013. Evaluation of haematological parameters among alcoholics in Port Harcourt Nigeria. International Journal of Laboratory Haematology, pp 107-108.

[4] Ernst, E; Matrai, A; Schmolzel, H and Magyrarosy, I ( 1987). Dose-effect relationship between smoking and blood rheology. Br J Haematol 65; pp 485 - 487.

[5] Cochran, W (1977). Sampling techniques, $3^{\text {rd }}$ ed.. New York: JohnWiley and sons, pp78-79.

[6] Inal, B; Hacibekiroglu, T; Cavus, B; Musaoglu, Z; Demir, H and Karadag, B (2014). Effects of smoking on healthy young men's haematologic parameters. Northern Clinics of Istanbul 1(1); pp19-25.

[7] Kapoor, D; Jones, T (2005). Smoking and hormones in health and endocrine disorders. European Journal of Endocrinology 152(4); pp 491-499.

[8] Jaana, L 2016. Effect of alcohol consumption and acetaldehyde on blood cells and molecules, Pathogenic and Diagnostic Implications. Mediwest Health Technology Centre, Koskenalantie 16.

[9] Latvala, J; Hietala, J; Koivisto; Jarvi, K; Anttila, P and Niemelä, O (2005). Immune responses to ethanol metabolites and cytokine profiles differentiate alcoholics with or without liver disease. AM J Gastroenterol 100; pp 1303 - 1310.

[10] Maja, M; Besim, P and Adiija (2017). Effect of cigarette smoking on haematological parameters in healthy population. The Academy of Medical Sciences of Bosnia and Herzegovina 55(1); pp 15-31.

[11] Oduola, T; Adeosun, G; Oduola, A; Agbaje, R and Raheem, A (2005). Drinking patterns; biochemical and haematological findings in alcohol Consumers in IleIfe, Nigeria. African Journal of Biotechnology 4(11); pp1304-1308.

[12] Vatn, M 2008. The effect of pentagastrin secretion and cholecystokinin on the intrinsic factor secretion in man. American journal of medicine 29; pp 53-56. 